\title{
A Note on Romanization
}

This book employs the pinyin system for the transliteration of Chinese names. Developed on the mainland, this system is currently becoming standard around the world. Thus familiar names such as Chou En-lai, Mao Tse-tung, Peking, and Nanking appear in the text in the slightly more novel forms of Zhou Enlai, Mao Zedong, Beijing, and Nanjing. Futhermore, in keeping with Chinese language source references, Sun Yatsen and Chiang Kaishek are referred to as Sun Zhongshan and Jiang Jieshi. In citing Western language sources that use the older Wade-Giles romanization system, however, references to persons and places were left unchanged. Finally, unless otherwise indicated, all translations are the author's own renditions. 